\title{
Deoxyribonucleic Acid Sequence Relatedness Between Thermophilic Members of the Genus Campylobacter
}

\author{
By ROBERT J. BELLAND AND TREVOR J. TRUST* \\ Department of Biochemistry and Microbiology, University of Victoria, Victoria, \\ British Columbia V8W 2Y2, Canada
}

(Received 23 December 1981; revised 13 April 1982)

\begin{abstract}
The genomic relatedness among 28 catalase-positive Campylobacter strains was assessed by determination of DNA base composition, by DNA : DNA hybridization followed by S1 endonuclease digestion of single-stranded DNA, and by determining the thermal stability of homologous and heterologous double-stranded DNA. The catalase-positive Campylobacter strains were shown to comprise 3 species, $C$. coli, $C$ fetus and $C$. jejuni; each included the type strain (respectively, CIP 7080, CIP 5396 and CIP 702).
\end{abstract}

\section{INTRODUCTION}

The genus Campylobacter contains Gram-negative curved or spiral bacteria which are microaerophilic. The catalase-positive members of the genus cause abortion and infertility in cattle, abortion in sheep, and are associated with dysentery in swine (Smibert, 1978). Certain members of the genus have recently been recognized as a common source of acute enteritis in man (Butzler et al., 1973; Skirrow, 1977).

Almost all the strains associated with acute enteritis are able to grow at $42-43{ }^{\circ} \mathrm{C}$ (Butzler \& Skirrow, 1979). These were first described by King (1957) who called them 'related vibrios'. The taxonomy of these thermophilic campylobacters has been based on a limited number of phenotypic characters and has always been controversial. Véron \& Chatelain (1973) considered them as belonging to two species, Campylobacter jejuni and Campylobacter coli. In the 8th edition of Bergey's Manual of Determinative Bacteriology, Smibert (1974) included these strains in a single subspecies, Campylobacter fetus subsp. jejuni. The Approved Lists of Bacterial Names (Skerman et al., 1980), adopted the nomenclature of Véron \& Chatelain (1973). Most recently Skirrow \& Benjamin $(1980,1982)$ proposed that the group be divided into $C$. jejuni biotype $1, C$. jejuni biotype 2, C. coli and nalidixic acid-resistant thermophilic campylobacters (NARTC) according to nalidixic acid sensitivity, hippurate hydrolysis, and $\mathrm{H}_{2} \mathrm{~S}$ production in an ironcontaining medium. Campylobacter jejuni biotype 1 is the type most often isolated from patients suffering from acute enterocolitis, but $C$. jejuni biotype 2 and $C$. coli are also found. NARTC strains are rarely isolated from man and so far are not associated with illness (Skirrow \& Benjamin, 1982).

While these phenotypic groupings may be most useful practically, the precise definition of the taxonomic relationships between related organisms requires a knowledge of DNA sequence homologies. Because of the controversy surrounding the taxonomic relationships within the genus Campylobacter, we have determined the DNA homologies between type, reference and wild-type strains of various species of Campylobacter from human and animal sources.

\section{METHODS}

Bacterial strains. The strains of Campylobacter examined in this study are listed in Table 1. Vibrio anguillarum ATCC 14181 (NCMB 829, National Collection of Marine Bacteria, Aberdeen, Scotland) and Escherichia coli B ATCC 11303 were also used.

Abbreviation: NARTC, nalidixic acid-resistant thermophilic campylobacters 
Table 1. Strains of Campylobacter used in this study

\begin{tabular}{|c|c|c|}
\hline Species & Strain number* & Source $\dagger$ \\
\hline Campylobacter coli & $\begin{array}{l}\text { CIP } 7080(\text { NCTC 11366) } \ddagger \\
\text { Z2 } \\
\text { Soton } 11 \\
\text { Soton } 12 \\
8466 \\
2555 \\
\text { C-602 } \\
\text { Pen } 5 \\
\text { Pen 30 } \\
\text { Pen } 46 \\
\text { Pen } 48\end{array}$ & $\begin{array}{l}\text { Pig faeces, CIP } \\
\text { Human faeces, Butzler } \\
\text { Human faeces, Pearson } \\
\text { Human faeces, Pearson } \\
\text { Human blood, Skirrow } \\
\text { Pig faeces, Skirrow } \\
\text { Human faeces, Lior } \\
\text { Human faeces, Penner } \\
\text { Human faeces, Penner } \\
\text { Human faeces, Penner } \\
\text { Human faeces, Penner }\end{array}$ \\
\hline Campylobacter fetus & $\begin{array}{l}\text { NCTC } 10348 \\
\text { CIP } 6829 \text { (NCTC 10354, ATCC 19438) subsp. } \\
\text { venerealis } \ddagger \\
\text { CIP } 5396 \text { (NCTC 10842, ATCC 27374) subsp. } \\
\text { fetus } \ddagger \\
\text { VC } 75\end{array}$ & $\begin{array}{l}\text { Vaginal mucus of heifer, NCT } \\
\text { Vaginal mucus of heifer, CIP } \\
\text { Sheep foetus brain, CIP } \\
\text { Human blood, this laboratory }\end{array}$ \\
\hline Campylobacter jejuni & $\begin{array}{l}\text { CIP } 702 \text { (NCTC } 11351) \text { biotype } 1 \ddagger \\
\text { ATCC } 29428 \text { biotype } 1 \\
\text { NCTC } 11168 \text { biotype } 1 \| \\
\text { C-130 biotype } 1 \\
1123-47578 \text { biotype } 1 \\
1125-47614 \text { biotype } 1 \\
79-159 \text { biotype } 1 \\
\text { VDP-3 biotype } 1 \\
\text { Soton } 3 \text { biotype } 1 \\
\text { Soton } 5 \text { biotype } 1 \\
\text { VC } 74 \text { biotype } 1 \\
\text { NCTC } 11392 \text { biotype } 2 \| \\
\text { NCTC } 11352 \text { NARTC } \|\end{array}$ & $\begin{array}{l}\text { Human faeces, CIP } \\
\text { Human faeces, ATCC } \\
\text { Human faeces, NCTC } \\
\text { Human faeces, Lior } \\
\text { Human faeces, McDermott } \\
\text { Human faeces, McDermott } \\
\text { Dog faeces, Blaser } \\
\text { Human blood, Butzler } \\
\text { Human faeces, Pearson } \\
\text { Human faeces, Pearson } \\
\text { Human faeces, this laboratory } \\
\text { Human faeces, NCTC } \\
\text { Herring gull, NCTC }\end{array}$ \\
\hline Campylobacter sputorum & NCTC 10355 subsp. bubulus & Bovine semen \\
\hline
\end{tabular}

* NCTC, National Collection of Type Cultures, London, England; CIP, Collection de l'Institut Pasteur, Paris, France; ATCC, American Type Culture Collection, Maryland, U.S.A.

$\dagger$ H. Lior, Laboratory Centre for Disease Control, Ottawa, Ontario, Canada; S. McDermott, Institute of Medical and Veterinary Science, Adelaide, Australia; M. Blaser, Centre for Disease Control, Atlanta, U.S.A.; J. P. Butzler, St Pierre Hospital, University of Brussels, Belgium; A. D. Pearson, Public Health Laboratory, Southampton, England; M. B. Skirrow, Worcester Royal Infirmary, England; J. L. Penner, University of Toronto, Ontario, Canada.

$\ddagger$ Type strain.

$\S$ Type species of genus.

|) Recommended control strain (Skirrow \& Benjamin, 1982).

Culture media and growth conditions. Mueller-Hinton agar (MH, Difco) was used. All strains were grown in anaerobic jars at $37{ }^{\circ} \mathrm{C}$ for $48 \mathrm{~h}$ in a $5 \%$ oxygen, $10 \% \mathrm{CO}_{2}$ atmosphere provided by a gas-generating kit for campylobacters (Oxoid). Escherichia coli and Vibrio anguillarum strains were cultured aerobically on Trypticase Soy Agar (TSA, BBL Microbiology Systems) at $37^{\circ} \mathrm{C}$ and $30^{\circ} \mathrm{C}$, respectively.

Isolation of DNA. Cells were harvested into $50 \mathrm{ml}$ saline/EDTA $(0 \cdot 15 \mathrm{M}-\mathrm{NaCl}, 0 \cdot 1 \mathrm{M}-\mathrm{EDTA}, \mathrm{pH} 8)$ and centrifuged for $20 \mathrm{~min}$ at $17000 \mathrm{~g}$. Sufficient numbers of culture plates to provide $2-3 \mathrm{~g}$ wet-packed cells were used. The cell pellet was resuspended and washed again in $50 \mathrm{ml}$ saline/EDTA and the DNA extracted by the chloroform/isoamyl alcohol method of Marmur (1961). DNA purity was assessed from the $258: 230$ and $258: 280$ absorbance ratios, and pronase, RNAase, and chloroform/isoamyl alcohol extraction treatments were repeated until the absorbance ratios were greater than $2 \cdot 0$ and $1 \cdot 8$, respectively. DNA samples were then dialysed for $48 \mathrm{~h}$ against distilled water followed by dialysis for $48 \mathrm{~h}$ against $0.42 \mathrm{M}-\mathrm{NaCl}$ and then were stored at $-80^{\circ} \mathrm{C}$.

Estimation of DNA base composition. The base composition of the DNA was estimated from the thermal denaturation temperature $\left(T_{m}\right)$ according to Owen et al. (1969). Thermal denaturation was measured in $0 \cdot 1 \times$ SSC buffer (SSC is $0.15 \mathrm{M}-\mathrm{NaCl}$ buffered with $0.015 \mathrm{M}$-trisodium citrate at $\mathrm{pH} \mathrm{7.0}$ ) in increments of $0.5^{\circ} \mathrm{C} \mathrm{min}^{-1}$ in a Gilford 250 spectrophotometer equipped with a Gilford 2527 thermoprogrammer, 6046 analog multiplexer, and a 6051 recorder. Generally three samples were measured simultaneously with a fourth cuvette containing an adenine 
blank to enable correction for solvent expansion. The DNA base composition was expressed as percentage guanine plus cytosine relative to the total base content $(\mathrm{mol} \% \mathrm{G}+\mathrm{C})$.

Radiolabelling of DNA. In vitro labelling of DNA prepared by the Marmur (1961) method was done using the 'nick-translation' procedure of Rigby et al. (1977) with slight modification. Cold DNA (2 $\mu$ g) was nicked by DNAase I $\left(100 \mathrm{ng} \mathrm{ml}^{-1}\right.$, Bethesda Research Laboratories, BRL) in the presence of $300 \mathrm{pmol}(1.8 \mu \mathrm{M}$ final concentrations) each of deoxyguanosine $5^{\prime}$-triphosphate, thymidine $5^{\prime}$-triphosphate, deoxy $\left[5-{ }^{3} \mathrm{H}\right]$ cytidine $5^{\prime}$ triphosphate $\left[1.0 \mathrm{mCi} \mathrm{ml}^{-1}, 21 \mathrm{Ci} \mathrm{mmol}^{-1}\left(777 \mathrm{GBq} \mathrm{mmol}^{-1}\right)\right]$ and deoxy $\left[8{ }^{-3} \mathrm{H}\right]$ adenosine $5^{\prime}$-triphosphate $[1 \cdot 0 \mathrm{mCi}$ $\left.\mathrm{ml}^{-1}, 19 \cdot 2 \mathrm{Ci} \mathrm{mmol}^{-1}\left(710 \mathrm{GBq} \mathrm{mmol}^{-1}\right)\right]$ (Amersham) at $15^{\circ} \mathrm{C}$ in translation reaction buffer $(0-05 \mathrm{M}-\mathrm{Tris} / \mathrm{HCl}$,

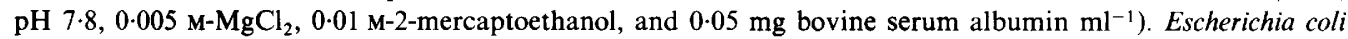
DNA polymerase I ( 3 units, Boehringer Mannheim) was added and the reaction allowed to proceed for $1 \mathrm{~h}$ at $15^{\circ} \mathrm{C}$. The reaction was stopped by deproteinization with an equal volume of chloroform/isoamyl alcohol. Labelled DNA was separated from unreacted nucleoside triphosphates on a Sephadex G-50 column equilibrated with Rigby buffer ( $0.01 \mathrm{M}$-Tris/HCl, pH $8,0.01 \mathrm{M}-\mathrm{NaCl}, 0.002 \mathrm{M}-\mathrm{EDTA})$. Fractions containing labelled DNA were pooled and dialysed against distilled water then $0.42 \mathrm{M}-\mathrm{NaCl}$ as before. Specific activities of approximately 2-3 $\times 10^{7}$ c.p.m. ( $\mu$ g DNA) ${ }^{-1}$ were obtained.

$D N A$ : DNA hybridization. Prior to hybridization, the DNA concentration was adjusted to approximately $70 \mu \mathrm{g}$ $\mathrm{ml}^{-1}$, aild solutions were sonicated for three periods of $1 \mathrm{~min}$ at $4{ }^{\circ} \mathrm{C}$ at a frequency of $20-25 \mathrm{kHz}$ and an amplitude of $2-5 \mu \mathrm{m}$ in a $150 \mathrm{~W}$ ultrasonic disintegrator (Branson Sonifier model 185E). Fragment sizes were estimated by agarose $(1.2 \%, \mathrm{w} / \mathrm{v})$ gel electrophoresis with bacteriophage $\lambda$ DNA HindIII fragments (BRL) as standard. The sonication procedure yielded fragments with an approximate molecular mass of $2.5 \times 10^{5}$.

Hybridization experiments were carried out for $20 \mathrm{~h}$ in $0.42 \mathrm{M}-\mathrm{NaCl}$ at $55^{\circ} \mathrm{C}$ (optimal reassociation temperature) and $70^{\circ} \mathrm{C}$ (stringent reassociation temperature) as described previously (Macinnes et al., 1979). These temperatures were chosen after establishing that the thermal denaturation temperatures in $0.42 \mathrm{M}-\mathrm{NaCl}$ were between 84 and $86^{\circ} \mathrm{C}$ for reference $C$. coli and $C$. jejuni DNA samples. The optimal reassociation temperature was taken as $85-30^{\circ} \mathrm{C}$ (Wetmur \& Davidson, 1968) and was confirmed by hybridization experiments. The stringent reassociation temperature was taken as $T_{m}-15^{\circ} \mathrm{C}$ (Wetmur \& Davidson, 1968). The extent of polynucleotide sequence homology was estimated by calculating the ratio of the amount of radiolabelled probe present in the $\mathrm{S} 1$-treated and untreated samples following subtraction of the S1-resistant 'core' material ( $8 \cdot 1$ $\pm 1.7 \%$ at $55^{\circ} \mathrm{C}$ and $9.7 \pm 1.9 \%$ at $70{ }^{\circ} \mathrm{C}$ ). Zero-time binding values did not differ significantly from these values. Results were then normalized to the homologous reassociation values $(62-80 \%)$ after correction for selfreassociation of labelled DNA $(<3 \%)$.

Estimation of sequence divergence. The susceptibility of homologous and heterologous double-stranded DNA to S1 endonuclease as a function of temperature was determined according to Crosa et al. (1973). The temperature at which $50 \%$ of the labelled DNA was rendered TCA soluble by $\mathrm{S} 1$ endonuclease was the melting temperature $T_{m(e)}$ of the duplex. The difference between the $T_{m(e)}$ for homologous and heterologous double-stranded DNA is defined as $\Delta T_{m(e)}$. A decrease in $T_{m(e)}$ of $1.0{ }^{\circ} \mathrm{C}$ was taken to correspond to approximately $1 \%$ base mismatching or base sequence divergence (McConaughy \& McCarthy, 1970). The $\Delta T_{m(e)}$ values were determined for double-stranded DNA reassociated at $55^{\circ} \mathrm{C}$.

\section{RESULTS}

\section{Mean DNA base compositions}

The DNA base compositions of the 20 Campylobacter strains examined (Table 2) were broadly distributed in the range 29.0 to $35.4 \% \mathrm{GC}$, within which were two narrower ranges. The 33.6 to $35.4 \% \mathrm{GC}$ range comprised the 3 strains of $C$. fetus, while the 29.0 to $32.9 \%$ GC range comprised the 16 thermophilic campylobacters and a representative strain of $C$. sputorum subsp. bubulus. These base composition results were in general agreement with the previously published data for members of the genus Campylobacter also given in Table 2 (Neill et al., 1979; Véron \& Chatelain, 1973; Owen \& Leaper, 1981).

\section{DNA-DNA hybridization}

Tables 3 and 4 list the percentage homologies obtained in reassociation experiments and $\Delta T_{m(e)}$ values for selected strains. Each $\Delta T_{m(e)}$ value was determined at least twice and the standard deviation did not exceed $\pm 0.5^{\circ} \mathrm{C}$. The standard deviation for triplicate determinations of percentage homology did not exceed $\pm 2.5 \%$ at the $55^{\circ} \mathrm{C}$ reassociation temperature or $\pm 4 \%$ at $70{ }^{\circ} \mathrm{C}$. Reciprocal reassociation reactions performed at $55^{\circ} \mathrm{C}$ with four reference DNAs 
Table 2. Base composition of genome DNA from strains of Campylobacter

\begin{tabular}{|c|c|c|c|}
\hline DNA source & $\begin{array}{l}\text { Mean } T_{m}{ }^{*} \\
\quad\left({ }^{\circ} \mathrm{C}\right)\end{array}$ & $\begin{array}{l}\mathrm{G}+\mathrm{C} \\
(\mathrm{mol} \%)\end{array}$ & Published $\mathrm{G}+\mathrm{C}$ values $(\mathrm{mol} \%)$ \\
\hline \multicolumn{4}{|l|}{ C. coli } \\
\hline CIP 7080 & $66 \cdot 2$ & $31 \cdot 3$ & $\begin{array}{l}32 \cdot 5 \text { (Véron \& Chatelain, 1973); } 32 \cdot 3 \text { and } 31 \cdot 2 \\
\text { (Owen \& Leaper, 1981) }\end{array}$ \\
\hline $\mathrm{Z} 2$ & $65 \cdot 6$ & $30 \cdot 0$ & \\
\hline Soton 11 & $66 \cdot 0$ & $30 \cdot 9$ & \\
\hline Soton 12 & $67 \cdot 0$ & $32 \cdot 9$ & \\
\hline 2555 & $66 \cdot 6$ & $32 \cdot 1$ & \\
\hline Species mean \pm S.D. & & $31 \cdot 4 \pm 1 \cdot 1$ & $\begin{array}{l}33.3 \text { (Véron \& Chatelain, 1973); } 32.6 \text { and } 31.4 \\
\text { (Owen \& Leaper, 1981) }\end{array}$ \\
\hline \multicolumn{4}{|r|}{ - } \\
\hline NCTC 10348 & $67 \cdot 5$ & $34 \cdot 0$ & 34.3 (Neill et al., 1979); 36.7 (Owen \& Leaper, 1981) \\
\hline $\begin{array}{l}\text { CIP } 6829 \text { subsp. } \\
\text { venerealis }\end{array}$ & $68 \cdot 2$ & $35 \cdot 4$ & $\begin{array}{l}35 \cdot 7 \text { (Neill et al., 1979); } 36 \cdot 3 \text { and } 36 \cdot 5 \\
\quad(\text { Owen \& Leaper, 1981) }\end{array}$ \\
\hline CIP 5396 subsp. fetus & $67 \cdot 3$ & $33 \cdot 6$ & $\begin{array}{l}33 \cdot 1 \text { (Véron \& Chatelain, 1973); } 36 \cdot 3 \text { and } 35.5 \\
\text { (Owen \& Leaper, 1981) }\end{array}$ \\
\hline Species mean \pm S.D. & & $34 \cdot 3 \pm 0 \cdot 95$ & $\begin{array}{l}35 \cdot 4 \text { (Véron \& Chatelain, 1973); } 36 \cdot 3 \text { and } 36 \cdot 2 \\
\text { (Owen \& Leaper, 1981) }\end{array}$ \\
\hline \multicolumn{4}{|l|}{ C. jejuni } \\
\hline CIP 702 biotype 1 & $66 \cdot 0$ & $30 \cdot 9$ & $\begin{array}{l}31.5 \text { (Véron \& Chatelain, 1973); } 31.6 \text { and } 30 \cdot 1 \\
\text { (Owen \& Leaper, 1981) }\end{array}$ \\
\hline ATCC 29428 & $65 \cdot 7$ & $30 \cdot 2$ & \\
\hline NCTC 11168 biotype 1 & $65 \cdot 3$ & $29 \cdot 4$ & 31.6 and 33.4 (Owen \& Leaper, 1981) \\
\hline C- 130 & $65 \cdot 8$ & $30 \cdot 4$ & \\
\hline $1123-47578$ & $65 \cdot 8$ & $30 \cdot 4$ & \\
\hline $1125-47614$ & $65 \cdot 8$ & $30 \cdot 4$ & \\
\hline $79-159$ & $65 \cdot 2$ & $29 \cdot 0$ & \\
\hline VDP-3 & $66 \cdot 0$ & 30.9 & \\
\hline Soton 3 & $65 \cdot 6$ & $30 \cdot 0$ & \\
\hline NCTC 11394 biotype 2 & $66 \cdot 6$ & $32 \cdot 1$ & 32.3 and 33.0 (Owen \& Leaper, 1981) \\
\hline NCTC 11352 NARTC & $66 \cdot 7$ & $32 \cdot 3$ & 32.6 and 32.5 (Owen \& Leaper, 1981) \\
\hline Species mean \pm S.D. & & $30 \cdot 6 \pm 1 \cdot 0$ & $\begin{array}{l}31 \cdot 6 \text { (Véron \& Chatelain, 1973); } 31 \cdot 8 \text { and } 32 \cdot 3 \\
\text { (Owen \& Leaper, 1981) }\end{array}$ \\
\hline \multicolumn{4}{|l|}{ C. sputorum subsp. bubulus } \\
\hline NCTC 10355 & $65 \cdot 9$ & $30 \cdot 6$ & $32 \cdot 2$ (Owen \& Leaper, 1981) \\
\hline Taxon mean \pm s.D. & & $31 \cdot 3 \pm 1 \cdot 6$ & $32 \cdot 1$ (Owen \& Leaper, 1981) \\
\hline \multicolumn{4}{|l|}{ E. coli } \\
\hline ATCC 11303 & $75 \cdot 3$ & $50 \cdot 3$ & 50 (Marmur \& Doty, 1962); 50.9 (DeLey, 1970) \\
\hline
\end{tabular}

gave homology values which differed by less than $3 \%$, suggesting that the genome sizes were not significantly different in the reference strains used.

The data show that the 28 strains of catalase-positive Campylobacter belonged to three discrete DNA homology groups. The first group (Table 3) contained 10 strains with high homology to C. coli CIP $7080\left(>79 \%\right.$ at $\left.55^{\circ} \mathrm{C}\right)$, intermediate homology to $C$. jejuni CIP $702(32-$ $48 \%$ at $55^{\circ} \mathrm{C}$ ) and low homology to $C$. fetus CIP $5396\left(<19 \%\right.$ at $\left.55^{\circ} \mathrm{C}\right)$. The second group (Table 3) contained 3 strains with high homology to C. fetus CIP $5396\left(>97 \%\right.$ at $\left.55^{\circ} \mathrm{C}\right)$ and low homology to both $C$. coli CIP 7080 and $C$. jejuni CIP $702\left(<18 \%\right.$ at $\left.55^{\circ} \mathrm{C}\right)$. The third group (Table 4) contained 11 strains with high homology $\left(>80 \%\right.$ at $\left.55{ }^{\circ} \mathrm{C}\right)$ to $C$. jejuni CIP 702 and $C$. jejuni ATCC 29428 , intermediate homology $\left(30-50 \%\right.$ at $\left.55^{\circ} \mathrm{C}\right)$ to $C$. coli CIP 7080 , and low homology $\left(<21 \%\right.$ at $\left.55^{\circ} \mathrm{C}\right)$ to $C$. fetus CIP 5396. Included in this DNA homology group were the recommended control strains for $C$. jejuni biotype 2 (NCTC 11392) and the NARTC group (NCTC 11352). Phenotypically, $C$. jejuni biotype 2 differs from $C$. jejuni biotype 1 by producing 
Table 3. DNA homologies $(\%)$ at reassociation temperatures of $55^{\circ} \mathrm{C}$ and $70^{\circ} \mathrm{C}$, and sequence divergence $\left[\Delta T_{m(e)}\right]$ between reference strains $C$. fetus CIP 5396, C. jejuni CIP 702 and $C$. coli

CIP 7080, and strains of C. coli, C. fetus, and C. sputorum subsp. bubulus

\begin{tabular}{|c|c|c|c|c|c|c|c|c|c|}
\hline \multirow[b]{3}{*}{$\begin{array}{c}\text { Source of } \\
\text { unlabelled DNA }\end{array}$} & \multicolumn{9}{|c|}{ Reference DNA from strain: } \\
\hline & \multicolumn{3}{|c|}{ C. coli CIP 7080} & \multicolumn{3}{|c|}{ C. fetus CIP 5396} & \multicolumn{3}{|c|}{ C. jejuni CIP 702} \\
\hline & $55^{\circ} \mathrm{C}$ & $70^{\circ} \mathrm{C}$ & $\begin{array}{c}\Delta T_{m(e)} \\
\left({ }^{\circ} \mathrm{C}\right)\end{array}$ & $55^{\circ} \mathrm{C}$ & $70^{\circ} \mathrm{C}$ & $\begin{array}{c}\Delta T_{m(e)} \\
\left({ }^{\circ} \mathrm{C}\right)\end{array}$ & $55^{\circ} \mathrm{C}$ & $70^{\circ} \mathrm{C}$ & $\begin{array}{c}\Delta T_{m(e)} \\
\left({ }^{\circ} \mathrm{C}\right)\end{array}$ \\
\hline \multicolumn{10}{|l|}{ C. coli } \\
\hline CIP 7080 & 100 & 100 & - & 14 & 9 & $11 \cdot 2$ & 32 & 19 & $6 \cdot 2$ \\
\hline Soton 11 & 100 & 100 & $0 \cdot 5$ & 16 & 11 & $12 \cdot 6$ & 48 & 23 & $5 \cdot 8$ \\
\hline 2555 & 100 & 94 & & 13 & 8 & & 42 & 25 & \\
\hline Pen 5 & 100 & 100 & & 19 & 14 & & 44 & 20 & \\
\hline $\mathrm{Z} 2$ & 99 & 100 & & 9 & 2 & & 42 & 22 & \\
\hline C-602 & 98 & 90 & & 8 & 6 & & 39 & 30 & \\
\hline Pen 46 & 95 & 87 & & 13 & 10 & & 45 & 28 & \\
\hline 8446 & 86 & 79 & & 19 & 17 & & 40 & 25 & \\
\hline Pen 30 & 83 & 73 & $2 \cdot 3$ & 16 & 12 & $12 \cdot 1$ & 46 & 31 & $5 \cdot 4$ \\
\hline Soton 12 & 81 & 88 & $1 \cdot 2$ & 7 & 4 & $13 \cdot 8$ & 32 & 20 & $7 \cdot 1$ \\
\hline Pen 48 & 79 & 62 & & 14 & 10 & & 41 & 29 & \\
\hline \multicolumn{10}{|l|}{ C. fetus } \\
\hline CIP 5396 subsp. fetus & 17 & 12 & $10 \cdot 9$ & 100 & 100 & - & 14 & 19 & $14 \cdot 0$ \\
\hline CIP 6829 subsp. venerealis & 11 & 10 & & 100 & 100 & 0.4 & 15 & 12 & \\
\hline VC 75 & 18 & 11 & & 100 & 89 & & 12 & 20 & \\
\hline NCTC 10354 & 14 & 13 & & 97 & 90 & 0.7 & 18 & 15 & \\
\hline \multicolumn{10}{|l|}{ C. sputorum subsp. bubulus } \\
\hline NCTC 10355 & 18 & 11 & & 11 & 10 & & 7 & 4 & \\
\hline \multicolumn{10}{|l|}{$V$. anguillarum } \\
\hline ATCC 14181 & 7 & & & 9 & & & 4 & & \\
\hline \multicolumn{10}{|l|}{ E. coli } \\
\hline ATCC 11303 & 2 & & & 7 & & & 3 & & \\
\hline
\end{tabular}

$\mathrm{H}_{2} \mathrm{~S}$ in an iron-containing medium, while NARTC strains, which also produce $\mathrm{H}_{2} \mathrm{~S}$, differ from $C$. jejuni biotypes 1 and 2 in their ability to grow in the presence of nalidixic acid and inability to hydrolyse hippurate (Skirrow \& Benjamin, 1980). The catalase-negative strain $C$. sputorum subsp. bubulus NCTC 10355 showed low homology to the reference DNAs as did the DNA of $V$. anguillarum ATCC 14181 and E. coli ATCC 11303.

Data obtained from reassociation at the stringent temperature of $70^{\circ} \mathrm{C}$ confirmed these 3 DNA homology groups, as did the $\Delta T_{m(e)}$ values. Within each homology group, increasing the reassociation temperature from $55^{\circ} \mathrm{C}$ to $70^{\circ} \mathrm{C}$ did not significantly reduce the homology value obtained. Similarly, $\Delta T_{m(e)}$ values within each group were normally low $\left(<2{ }^{\circ} \mathrm{C}\right)$, while values between homology groups were higher $\left(>5^{\circ} \mathrm{C}\right)$. There was one noticeable exception in the $C$. jejuni homology group. This was NCTC 11352, the recommended control NARTC strain. In this case the percentage homology with $C$. jejuni CIP 702 fell from 86 to 32 when the reassociation temperature was raised from $55^{\circ} \mathrm{C}$ to $70^{\circ} \mathrm{C}$, while the percentage homology with C. jejuni ATCC 29428 fell from 92 to 48. Predictably, in the case of NCTC 11352 the $\Delta T_{m(e)}$ value of $4{ }^{\circ} \mathrm{C}$ obtained with both $C$. jejuni reference DNAs was significantly higher than other intragroup values.

\section{DISCUSSION}

Brenner et al. (1972) demonstrated that when the hydroxyapatite method was used to assess genomic homology among bacteria, strains belonging to a single species usually exhibited more than $70 \%$ homology at optimal temperature, a slight decrease in relatedness at stringent 


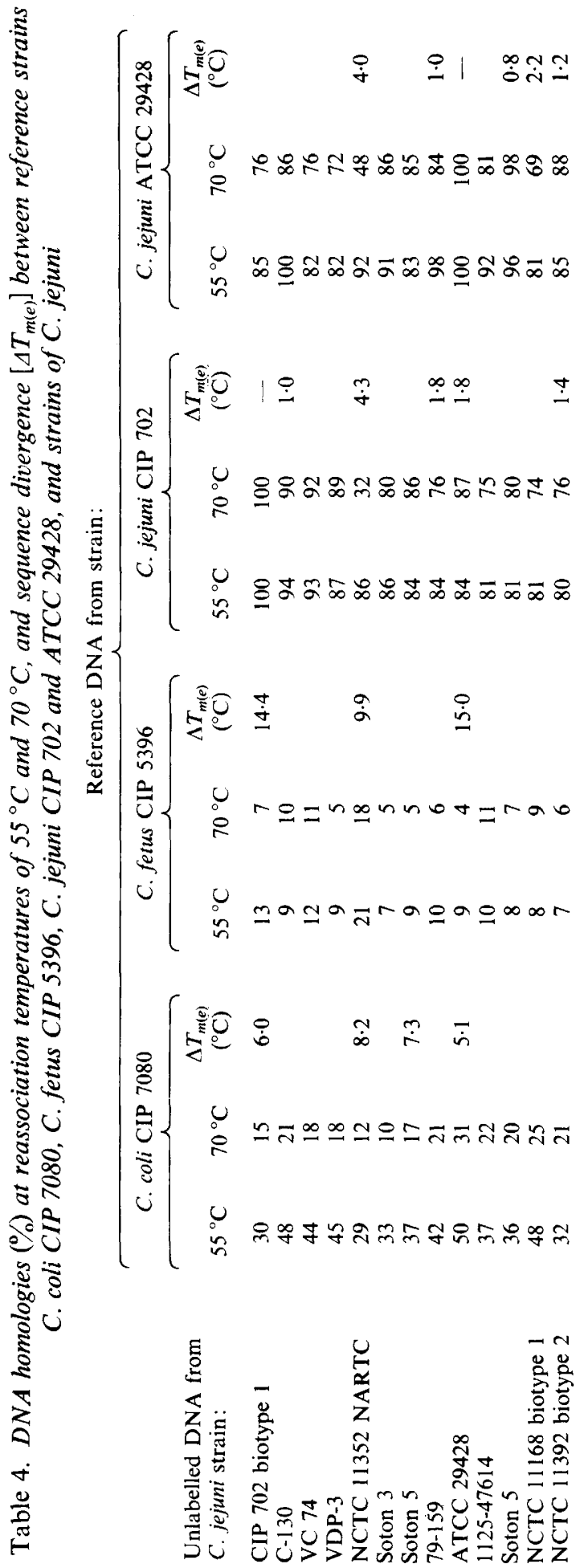


temperature, and less than $5 \%$ base sequence divergence. Grimont et al. (1980) recently demonstrated that the $70 \%$ homology value obtained with the hydroxyapatite method corresponded to $51-54 \%$ homology at optimal temperature and 64-66\% homology at stringent temperature with the S1 endonuclease/TCA precipitation technique used in this study. These workers also demonstrated that percentage divergence figures obtained with the two methods were directly comparable. When we applied these criteria to the values obtained for catalase-positive campylobacters, three species were clearly distinguishable. These were $C$. coli, C. fetus and $C$. jejuni.

Strains of $C$. fetus were highly related. Indeed, although the Approved Lists of Bacterial Names (Skerman et al., 1980) contain two subspecies, C. fetus subsp. fetus and C. fetus subsp. venerealis, they could not be differentiated on the basis of DNA homology. The type strain of $C$. fetus subsp. venerealis CIP 6829 was $100 \%$ homologous with the type strain of C. fetus (Smith and Taylor) Sebald and Véron CIP 5396 even at the stringent reassociation temperature. Moreover, the base sequence divergence between the two strains was $<1 \%$. The species $C$. fetus was only distantly related to the thermophilic campylobacters. The mean DNA homology between strains of $C$. fetus and strains of $C$. coli in this study was only $14 \%$ at $55^{\circ} \mathrm{C}$ and $10 \%$ at $70{ }^{\circ} \mathrm{C}$, with a mean base sequence divergence of $12 \%$. In the case of $C$. jejuni it was $11 \%$ at $55^{\circ} \mathrm{C}$, and $10 \%$ at $70{ }^{\circ} \mathrm{C}$, with a mean base sequence divergence of $13 \%$. C. fetus could also be differentiated from these thermophilic species on the basis of $\mathrm{G}+\mathrm{C}$ content.

The species $C$. coli and $C$. jejuni appeared to be more closely related to each other than to $C$. fetus. They could not be distinguished by $\mathrm{G}+\mathrm{C}$ content, and at $55^{\circ} \mathrm{C}$ the mean DNA homology between these thermophilic species was $40 \%$, with a mean base sequence divergence of $6 \%$. However, at the stringent reassociation temperature the mean inter-species DNA homology was reduced to $22 \%$, leaving no doubt that $C$. coli and $C$. jejuni are separate species. Within each species, strains displayed high DNA homology. In the case of $C$. coli, the mean DNA homology at the stringent reassociation temperature was $87 \%$, while the mean base sequence divergence was only $1 \%$. In the species $C$. jejuni, the mean DNA homology at the stringent reassociation temperature was $79 \%$, and the mean base sequence divergence was $2 \%$. Included among the strains belonging to this species were recommended control strains from the identification scheme recently proposed by Skirrow \& Benjamin (1982), NCTC 11352 representing the NARTC group of organisms, and NCTC 11392 representing $C$. jejuni biotype 2 . The $>80 \%$ homology shown by these strains to both $C$. jejuni reference DNAs at the optimal reassociation temperature clearly places them in the species $C$. jejuni as do the base sequence divergence values of $<5 \%$. However, the NARTC strain was distinguishable from other $C$. jejuni by its reduced homology at the stringent reassociation temperature, and by its higher base sequence divergence values. Clearly more NARTC strains need to be examined to determine whether they form a distinct genetic group, and, if so, to determine the relatedness of the group to the thermophilic campylobacters pathogenic for man. For the present, NCTC 11352 should be included in the species $C$. jejuni.

In summary, this DNA homology study has shown that the catalase-positive campylobacters comprise three species, $C$. coli, C. fetus, and $C$. jejuni. This confirms the concepts of the speciation within the genus Campylobacter first proposed by Véron \& Chatelain (1973). While DNA homology obviously provides the best basis for delineating bacterial species, the DNA homology grouping needs to be correlated with phenotypic characteristics to be useful for classification and identification. Although the identification and differentiation of campylobacters is based on a limited number of morphological and biochemical tests (Skirrow \& Benjamin, 1980; Karmali et al., 1981), two phenotypic characteristics appear to correlate with the differences in genomic homology. Phenotypically, $C$. fetus can be distinguished by its ability to grow at $25^{\circ} \mathrm{C}$ and inability to grow at $43{ }^{\circ} \mathrm{C}$, while $C$. coli and $C$. jejuni, which do grow in the temperature range $30.5-45.5^{\circ} \mathrm{C}$, can be differentiated by the inability of $C$. coli to hydrolyse hippurate (Skirrow \& Benjamin, 1982). Within the species $C$. jejuni, a strain representing a phenotypic subgroup able to grow in the presence of nalidixic acid, while not clearly delineated genetically, was sufficiently different to suggest that some genetic drift may be occurring within the species. 
This work was supported in part by a grant from the British Columbia Health Care Research Foundation to T. J.T. and a Natural Sciences and Engineering Research Council of Canada Postgraduate Scholarship to R. J.B. We thank all those who sent us bacterial strains and Dr A. MacArter whose valuable advice facilitated completion of this study.

\section{REFERENCES}

Brenner, D. J., Fanning, G. R. \& Steigerwalt, A. G. (1972). Deoxyribonucleic acid relatedness among species of Erwinia and between Erwinia species and other enterobacteria. Journal of Bacterio$\log y$ 110, 12-17.

Butzler, J. P. \& Skirrow, M. B. (1979). Campylobacter enteritis. Acta paediatrica belgica 32, 89-94.

Butzler, J. P., Dekeyser, P., Detrain, M. \& DEHAEN, F. (1973). Related vibrios in stools. Journal of Pediatrics 82, 493-495.

Crosa, J. H., Brenner, D. J. \& Falkow, S. (1973). Use of a single-strain specific nuclease for analysis of bacterial and plasmid deoxyribonucleic acid homoand heteroduplexes. Journal of Bacteriology 115, 904 911.

DE LEY, J. (1970). Reexamination of the association between melting point, buoyant density, and chemical base composition of deoxyribonucleic acid. Journal of Bacteriology 101, 738-754.

Grimont, P. A. D., Popoff, M. Y., Grimont, F., Coynault, C. \& Lemelin, M. (1980). Reproducibility and correlation study of three deoxyribonucleic acid hybridization procedures. Current Microbiology 4, 325-330.

Karmali, M. A., Allen, A. K., \& Fleming, P. C. (1981). Differentiation of catalase-positive campylobacters with special reference to morphology. International Journal of Systematic Bacteriology 31, 64-71.

KING, E. O. (1957). Human infections with Vibrio fetus and a closely related vibrio. Journal of Infectious Diseases 101, 119-128.

McConaughy, B. L. \& McCarthy, B. J. (1970). Related base sequences in the DNA of simple and complex organisms. VI. The extent of base sequence divergence among the DNA's of various rodents. Biochemical Genetics 4, 425-446.

Macinnes, J. I., Trust, T. J. \& Crosa, J. C. (1979). Deoxyribonucleic acid relationships among members of the genus Aeromonas. Canadian Journal of Microbiology 25, 579-586.

MARMUR, J. (1961). A procedure for the isolation of deoxyribonucleic acid from micro-organisms. Journal of Molecular Biology 3, 208-218.

MARMUR, J. \& DOTY, P. (1962). Determination of the base composition of DNA from its thermal denaturation temperature. Journal of Molecular Biology 5, 109-118.

Neill, S. D., Ellis, W. A. \& O'Brien, J. J. (1979).
Designation of aerotolerant Campylobacter-like organisms from porcine and bovine abortion to the genus Campylobacter. Research in Veterinary Science 27, 180-186.

OWEN, R. J. \& LeAPER, S. (1981). Base composition, size and nucleotide sequence similarities of genome deoxyribonucleic acids from species of the genus Campylobacter. FEMS Microbiology Letters 12, 395400.

Owen, R. J., Hill, L. R. \& Lapage, S. P. (1969). Determination of DNA base compositions from melting profiles in dilute buffers. Biopolymers 7, 503516.

Rigby, P. W. J., Dibckmann, M., Rhodes, C. \& Berg, P. (1977). Labelling DNA to high specific activity in vitro by nick translation with DNA polymerase I. Journal of Molecular Biology 113, 237-251.

Skerman, V. B. D., McGowan, V. \& SNEaTh, P. H. A. (1980). Approved lists of bacterial names. International Journal of Systematic Bacteriology 30, 225420.

SkIRROW, M. B. (1977). Campylobacter enteritis - a 'new' disease. British Medical Journal ii, 9-11.

SkIRROW, M. B. \& BENJAMIN, J. (1980). Differentiation of enteropathogenic Campylobacter. Journal of Clinical Pathology 33, 1122.

Skirrow, M. B. \& Benjamin, J. (1982). The classification of 'thermophilic' campylobacters and their distribution in man and domestic animals. In Campylobacter Epidemiology, Pathogenesis and Biochemistry, pp. 40-49. Edited by D. G. Newell. Lancaster, Boston \& The Hague: MTP Press Ltd.

SMIBERT, R. M. (1974). Genus II. Campylobacter Sebald and Véron 1963, 907. In Bergey's Manual of Determinative Bacteriology, 8th edn, pp. 207-211. Edited by R. E. Buchanan \& N. E. Gibbons. Baltimore: Williams \& Wilkins.

SMIBERT, R. M. (1978). The genus Campylobacter. Annual Review of Microbiology 32, 673-709.

VÉron, M. \& Chatelain, R. (1973). Taxonomic study of the genus Campylobacter Sebald and Véron and designation of the neotype strain for the type species Campylobacter fetus (Smith and Taylor) Sebald and Véron. International Journal of Systematic Bacteriology 23, 122-134.

Wetmur, J. G. \& Davidson, N. (1968). Kinetics of renaturation of DNA. Journal of Molecular Biology 31, 349-370. 